\title{
THE RHETORIC OF BODY, CLOTHING AND IDENTITY IN THE VITA AND GENESIS
}

\author{
Dietmar Neufeld \\ Guest Lecturer, Department of New Testament, Unisa \\ University of British Columbia
}

\begin{abstract}
This paper will concentrate on the dynamic relationship between body, clothing, and identity. Nakedness and clothing mark the bodies of Adam and Eve with religious, political, and social distinction and other forms of embodied social meaning such as the transition from one state to another, the transformation of bodies of honour to bodies of shame, and the refashioning of the conduits of God's power who is not about to countenance challenges to his honour as benefactor of the cosmos and humankind (Porter 1999, 4). In addition, the surfaces of their bodies are a significant site for the production and display of difference and their physical transformations and regulations essential to maintaining and regulating ancient Israel's power structures and social organization (Esler 2001, 26-30). In the Vita and Genesis, the management of the bodies of Adam and Eve is integral to the maintenance and definition of social relationship and rank between God and humans, desires, and social identities. ${ }^{1}$
\end{abstract}

Keywords: Body, Adornment, Social Hierarchy, Gender, Power

\section{Body Talk}

Before beginning with an analysis of the Vita and the passages in Genesis it is essential to consider the various theoretical constructs of the body currently in use. Numerous attempts in recent years to make sense of bodies in both society and popular culture have been made. In an amazing display of interest in the body, books and articles on the topic abound - from interest in the labouring body to the desiring body - the body as sign in modern culture is pampered, primped, tanned, pierced, tattooed, exercised, down sized, resized, messaged, starved, surgically enhanced, for the central purposes of image management and enhancement, conveying social values of protest, compliance, and influence, and reflecting current images of what is considered an aesthetically pleasing body (Sweeney and Hodder 2002 , 1). The body has become flexible and plastic, "a lifestyle accessory, a thing to be sculpted, shaped and stylized" (Hancock and Jagger 1998, 3). In addition, the body has become the site upon which political, social, and cultural interventions play themselves out in relation to medicine, disability, work, ethics, old age, sexuality, reproduction, food, clothing, adornment, and disease (Hancock and Jagger 1998, 1). As a result, socially constructed bodies have proliferated so that one can speak about medicalized bodies, consumer bodies, old bodies, homosexual bodies, disabled bodies, working bodies, desiring bodies, ethical bodies, deviant bodies, dead bodies, nude bodies, classical bodies, female

\footnotetext{
Dietmar Neufeld was an invited guest lecturer for the Eighth International Conference on Rhetoric and Scriptures: The Rhetoric(s) of Body Politics and Religious Discourse, 9-12 August 2004, Pretoria, South Africa.
} 
bodies, and gendered bodies (Sweeney and Hodder 2002, 1-11). Women's bodies in their complexity and feminist theories have combined to investigate issues pertinent to women's bodies, including pregnancy, childbirth, menstruation, menopause, reproductive technologies, the shaping of female bodies, beauty, eating disorders, body image, cosmetic surgery and body building (Brook 1999, vi). Under the scrutiny of feminist theory applying bodies of feminist knowledge, literary and social constructs of women's bodies have proliferated such that one can investigate reproducing bodies, sculpted bodies cut down to size, public bodies, objectified bodies, and virtual bodies (Brook 1999, ix-xiv).

In concert with this interest, a number of theoretical constructs have been offered that conceptualize the historical development and location of the body in society and culture. First, there is the notion that the body is merely a set of social practices culturally determined. In this view, the body as potential is realized through a range of socially regulated practices in which the body is trained, disciplined and socialized. Activities such as walking, experiencing shame, stigmatization, eating, and dressing, are the daily rituals through which we attend and train the body - it is a medium of culture. The body in such a view is a powerful symbolic form, a surface on which the central rules, hierarchies, and even metaphysical commitments of culture are inscribed - it is also a practical, direct locus of social control. Banally, through table manners and toilet habits, through apparently trivial routines, rules, and practices, culture is made body (Baker 1998, 241). A second construct conceptualizes the body as a system of signs - that is, that it conveys symbolic and social meaning in ritual, ceremony and religious practice. Best known for this approach is Douglas' (1978) work who concludes that the dietary laws of Leviticus are a means of thinking about social relations, purity and pollution. A third approach to the body understands the human body as a system of signs that stand for and express relations of power as a system of signs the body expresses hierarchies of power and authority that limit and control access to power (Turner 1991, 25-27).

As the examination of body and clothing demonstrates, every culture is not only an elaboration of specific kinds of ritual, costume and raiment but also an elaboration of a specific body-ideal and attitudes to bodily practices (Lingis 1994, vii). The body's gestures, stances, initiatives, positions, and desires are not simply the result of external stimulations that would provoke them but the result of cultural, social and group understanding of the body and its function (Lingis 1994, ix). Cultures, societies, groups and individuals therefore presuppose a number of bodily identities - assumed identity, attributed identity, optative identity, sexual identity, gendered identity - all constructed through the experience of the body (Lingis 1994, xi).

In the ancient world as in the modern, the human body "is a cultural costume: It is decorated from birth to death by diverse cultural traditions and is therefore at all times a medium of cultural communication" (Burton 1999, 2). My interest lies in the way in which the Vita and Genesis utilize the body surfaces of Adam and Eve to mark rank and relationship between males and females, authenticate identity, define power personally and socially, and keep aspirations in check (Porter 1999, 1). The body may be uncontrolled, undisciplined, expressive, and controlled, by which is signalled desire, whether sexual, sensual, or hierarchical (Brydon and Niessen 1998, 1). In the Vita and Genesis, the body and its adornment are critical to the production and authentication of identity, to regulating its dangerous potential, to defining social relations and organization, and to upholding the social values of the ancient Israelites especially by those in positions of influence who wished to maintain the status quo. 


\section{Approaches to the Genesis Account}

While several recent books offer fascinating assessments of the significance of the apparel of Adam and Eve in the Hebrew Bible and certain post biblical Jewish writings, none of them has dealt in a significant way with body, clothing and identity (Anderson, Stone and Tromp 1994, 55-81; Morris and Sawyer 1990, 74-90). It is Morris and Sawyer's (1990) edited volume $A$ Walk in the Garden: Biblical, Iconographical and Literary Images of Eden that will become the focus of my comments. A chapter by Lambden (1990, 74-90) concentrates on the nakedness and garment motifs of Gen 2:25, 3:7 and 3:21 and suggests a three-fold progression in the position or state of the first couple; (1) an initial nakedness and the lack of shame in that state, to (2) being attired in fig leaves, and then (3) being vested in designer "coats of skin." Assessing the significance of nakedness and the lack of shame of that state in Gen 2:25, Lambden $(1990,75)$ proposes that human relationships are initially stable, dignified and innocent. While nakedness and the loss of innocence are sometimes taken to be indicative of an emerging sexuality, Lambden $(1990,75)$ argues otherwise, pointing out that nakedness in the Hebrew Bible usually refers to the loss of human and social dignity. In this case, primordial nakedness and unashamedness are the focus and indicate that human relationships are characterized by mutual trust, innocence and respect before God. Genesis 2:25 points forward to both 3:1-2 in which the consequences of disobedience puts humankind at odds with God. Lambden $(1990,75)$ proposes that the forbidden fruit symbolizes human wisdom/experience that stands in opposition to divine wisdom - the act of eating symbolizes a turning away from God in an attempt to gain a level of human sophistication. Human wisdom, however, that stands outside the wisdom of God disturbs the harmony that is to exist between humans and God. Lambden $(1990,76)$ states, "even when initiated into the ways of the world, humankind ever stands in need of God." This need is symbolized, according to Lambden $(1990,76)$, in the act of the first couple covering up with fig-leaf aprons. While modern commentators have either ignored this act or have offered disappointing explanations of the significance of covering up with fig leaves, e.g., the size of fig leaves made it possible for them to sew a costume large enough to cover the body or that the fruit eaten was allegedly a fig and thus provided ironically the appropriate material, Lambden $(1990,75)$ is of the opinion that the act of making fig-leaf aprons in fact points to the foolishness of humans thinking that they can cover their nakedness despite their newly minted wisdom.

Given the subtle sexual illusion of the fig, the author of Genesis may also be warning of the dangers "of participation in fertility cults and rites" (Lambden 1990, 76). In contrast to the foolish act of Adam and Eve fashioning garments from fig leaves, God in his wisdom designs coats of skin for them. Lambden $(1990,76)$ fully exploits this tension in their analysis along with the ambiguity inherent in the Hebrew of apron (צ'בגרטה), rendered alternatively loincloths, girdles or sashes, signifying perhaps a less adequate means of attire

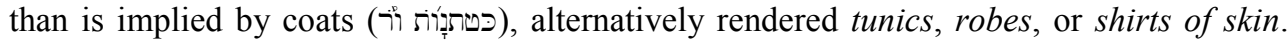
According to Lambden $(1990,77)$, the aprons and coats imply symbolically the folly of humans in contrast to the wisdom of God - their fig-leaf aprons served no real purpose. Indeed, "God's making of the coats of skin may be viewed as an expression of superior wisdom, his awareness of the real needs of his creatures in view of the imminent expulsion from the garden. The couples' limited sophistication will not adequately fit them for mundane post-edenic existence..." (Lambden 1990, 77). While some commentators have understood these passages from the perspective of sin, guilt, and an emergent sexuality that is the result of the fall and others have seen in these verses an aetiology of clothing, 
Lambden $(1990,76)$ is of the view that the verses are best understood in terms of the contrast between human folly and divine providence and wisdom.

While garments, ornamentation and the body play a considerable role in the Hebrew Bible, references to the clothing, ornaments and body of Adam and Eve are few. Postbiblical Jewish literature, however, contains a great deal of speculation about Adam's and Eve's apparel and body. ${ }^{2}$ Lambden $(1990,78-79)$ performs a valuable service by analyzing a fascinating and diverse series of texts in which Adam and sometimes Eve are pictured as royal, kingly, angelic, or divine figures clad in glorious garments of light - garments of glory that pious Jews hope to receive at the eschaton. In addition, the sources also speculate about the nature of Adam and Eve's attire and conclude that Adam and Eve were initially attired in splendiferous garments reflecting the glory of God; that Adam was attired in garments of priests handed down to him; that Adam and Eve were clothed in garbs of white; that the first couple's clothes were made from the shining skin of the leviathan; that Adam and Eve were initially clad in nail-skin - clothes that were smooth, tight-fitting, pearly, translucent and luminous, jewel-like; that the coats of skin were their fleshly skin or physical bodies; that the post-paradise clothes were made of either the skin or the fur of the goat, hare, lamb/sheep or weasel (Lambden 1990, 89).

Lambden's $(1990,74-90)$ analysis is intriguing but comes to conclusions that cannot be supported by the text and moreover fails to take into consideration the importance of the altered body as a powerful medium of expression. In the Vita and Genesis, the human body is central because the body provides a basis for the metaphors required for contemplating individual and social relations. "Dressing enacts one of the most complicated acts of daily existence. Dressing negotiates between the intensely personal and the prescribed and constructed layers of the social. Dressing both hides and lays bare body and soul..." (Brydon and Niessen 1998, xi).

It is clear from the Vita and Genesis that the garden promoted face-to-face encounters between God and the first humans - almost as if it were a kin-based society. The ambience in the garden was one of intimacy and comfortable familiarity. In such a context, there was a great density of common norms and values between God and Adam and Eve with a high degree of collective accountability (Burton 1999, 33). While this world was virtually absent of rules and regulations, one did apply that was subject to informal somatic control only they were not to eat of the tree. In such a setting, the body required little or no control and hence was unadorned - nakedness therefore was symbolic of the extensive sharing of values and aspirations common to both deity and humans. Once Adam and Eve challenged God and ate, they felt compelled to protect themselves from their shame before the other and God by regulating the body - they/God controlled the body by adorning it indicating that they no longer shared the same density of common values and norms with God. In this differentiated social state, Adam and Eve made a futile attempt to cover up. The cover up indicated their desire to retain a modicum of self-regulation of their bodies. Their bodies were, however, subsequently involuntarily covered with garments of skin by which God signaled that control of their bodies had been taken from them. God fashioning and then covering the naked bodies of Adam and Eve indicated that they were no longer subject to their own control - their bodies would from this point forward be regulated. The shame inherent in their nakedness was the recognition that they had relinquished the right to harness the potential of their bodies and that their bodies were now subject to public

See for example, Apocalypse of Baruch; Damascus Document; Ben Sira; Manual of Discipline; Jubilees; Apocalypse of Moses; Philo; Targum Onqelos. 
regulation (Burton 1999, 33). Interesting in this regard is that the body, not the intellect, provides the basis for knowledge. Adam and Eve knew with their bodies - the truth that they discover is the truth revealed via the body (Game 1991, 192). Human society, implicit in the Vita and Genesis, thought of the cosmos and society with their bodies, since the body not the mind is the chosen instrument of thought (O'Neill 1985, 28).

An additional appealing feature to be considered is the body in relationship to social practice and institutions in ancient Israel that are based on hierarchy and restricted access to power (Burton 1999, 34). The body stands at the centre in the debate of the broader issues of social and political control, communal identity and boundary construction. Both the Vita and Genesis promote a garden scene that appeared to mitigate the effects of hierarchy and access to power and hence also alleviated the necessity of bodily control - the naked body was initially the great social equalizer and emblematic of desires and ambitions held in check. The post-garden scenes make it clear that the situation has changed dramatically for Adam and Eve - among a host of changes, social practices and institutions were in place that were clearly hierarchical. The relationship between God and Adam and Eve was now based on power differential and inequality. Hierarchy became the basis of social control. The awareness of nakedness indicated separation not only between God and humans but also between humans, in which socially determined inequities, sexual inequalities, and gender distinctions were to become the norm. Adorning and attiring the bodies of Adam and Eve served to further these differences in a ranking system that demanded conformity and obedience to the requirements of Torah. Their bodies clothed became templates to delineate humans who were consigned to live a rule-governed existence.

The narratives of the primeval modification of the bodies of Adam and Eve function rhetorically to convey ideologies, attitudes, and values, of gender, status and control, nature and culture, and identity. Body discourses are linguistic practices that, if repeated often enough, eventually form the object about which they speak. Communal discourse about bodies constructs through rhetoric a vision of the ideal social order in order to convince an audience of the power and reality of that vision (Nasrallah 2003, 5). In the case of the Vita and Genesis, the narratives of altering the body through adorning it with clothing are used by the elites to catalog, screen, and control human desires and aspirations. The transformed bodies of Adam and Eve symbolize the social body constrained. Bodily issues, such as knowledge, desire, power, and gender, are defined vis-à-vis the changing contours of the body (Burton 1999, 32).

\section{Conclusions}

Both the Vita and Genesis make powerful statements about individuals and societies through arranging the temporary skin of Adam and Eve - their bodies are vested initially with leaves and subsequently with garments of skin to mark the problematic and constantly shifting boundaries of gender, power, and ambition (Burton 1999, 66). Their vested bodies were eventually to become part "of a system of cultural stratification which held individuals and groups in competitive, endogamous and self-perpetuating hierarchies of symbolic domination and control" (Keenan 2001, 31). Thus, the first human bodies were subject to cultural control in much the same way that social systems were also controlled and ordered to keep inappropriate aspirations at bay. Managing the bodies of Adam and Eve simultaneously controlled ancient Jewish society resonant with its cultural and religious predispositions and empowered the influence brokers of that society (Douglas 1978). 


\section{BIBLIOGRAPHY}

Anderson, GA and Stone, ME 1999. A Synopsis of the Book of Adam and Eve. $2^{\text {nd }}$ ed. Society of Biblical Literature Early Judaism and Its Literature 17. Atlanta.

Anderson, GA, Stone ME and Tromp, J (eds.) 1994. Literature on Adam and Eve. Leiden: Brill.

Baker, CM 1998. "Ordering the House": On the Domestication of Jewish Bodies. Pages 203-229 in Parchments of Gender. Edited by M Wyke. Oxford: Clarendon Press.

Brook, B 1999. Feminist Perspectives on the Body. London: Longman.

Brydon, A and Niessen, S (eds.) 1998. Consuming Fashion. Adorning the Transnational Body. Oxford: Berg.

Burton, JW 1999. Culture and the Human Body. Illinois: Waveland Press.

Douglas, M 1978. Purity and Danger. London: Routledge \& Kegan Paul.

Esler, PF 2001. Palestinian Judaism in the First Century. Pages 21-46 in Religious Diversity in the Graeco-Roman World. A Survey of Recent Scholarship. Edited by D CohnSherbok and JM Court. Sheffield: Sheffield Academic Press.

Game, A 1991. Undoing the Social. Towards a Deconstructive Sociology. Milton Keynes: Oxford University Press.

Hancock, P and Jagger, E (eds.) 1998. The Body, Culture and Society. Buckingham, Philadelphia: Open University Press.

Keenan, WJF (ed.) 2001. Dressed to Impress. Looking the Part. Oxford: Berg.

Lambden, SN 1990. From Fig Leaves to Fingernails: Some Notes on the Garments of Adam and Eve in the Hebrew Bible and Select Early Post Biblical Jewish Writings. Pages 74-90 in $A$ Walk in the Garden. Biblical, Iconographical and Literary Images of Eden. Edited by P Morris and D Sawyer. Sheffield: Sheffield Academic Press.

Lingis, A 1994. Foreign Bodies. New York: Routledge.

Morris, P and Sawyer, D (eds.) 1990. A Walk in the Garden. Biblical, Iconographical and Literary Images of Eden. Sheffield: Sheffield Academic Press.

Nasrallah, L 2003. An Ecstasy of Folly. Prophecy and Authority in Early Christianity. Cambridge: Harvard University Press.

O’Neill, J 1985. Five Bodies. The Human Shape of Modern Society. Ithica: Cornell University Press.

Porter, J.I., (ed.) 1999. Constructions of the Classical Body. Ann Arbor: The University of Michigan Press.

Sweeney, ST and Hodder, I (eds.) 2002. Body. Cambridge: Cambridge University Press.

Turner, BS 1991. The Body: Social Process and Cultural Theory. London: Sage Publications. 